\title{
Subsidization in China's Renewable Energy Sector: Negotiability as the Norm
}

\author{
NIS HØYRUP CHRISTENSEN
}

\begin{abstract}
The Chinese government's decision to push for large-scale build up of renewable energy capacity was followed by a range of industrial policies to support this change of track. Most importantly, various forms of subsidies were launched to support both industries and markets. While important new research has added to our understanding of China's state capitalism by documenting the depth and breadth of subsidies to solar PV manufactures, very little attention has been paid to how subsidies are determined and how companies influence these processes. This article takes a neo-institutional perspective with the aim of understanding the institutional context for the interplay between companies and Party-state, and the norms established through this interaction. It explores two cases, the biomass and solar industry, and shows how subsidies are perceived as being negotiable. Understanding this negotiability of subsidies as an institutionalized norm helps us understand both an important factor shaping China's renewable energy sector and the wider dynamics of state capitalism in China.
\end{abstract}

Keywords: China, Renewable energy, Subsidies, Neo-institutional theory, State capitalism

\section{Introduction}

Amidst rapidly increasing energy consumption and emission of greenhouse gases China has also emerged as the world's biggest investor in renewable energy. At the heart of China's effort to develop renewable energy are its subsidy schemes. As in any other country, there can be no large scale renewable energy without subsidies. Despite its economic might, the Chinese state still has funding limitations and needs to consider and prioritize where and what to subsidize. This makes subsidization a delicate question, not least for companies that require subsidies as a precondition to the existence of a market. Subsidies, therefore, have become the focal point for the industry, with crucial formative effects on market size and the investment horizon.

Important new research has documented the scale of subsidies to capital-intensive industries in China and has thereby drawn further 
attention to an already hot topic in international trade (Haley and Haley 2013). However, questions about how specific subsidies are decided upon and, in particular, why they are allocated in specific ways, is not explored further than pointing to state capitalism as the most appropriate framework for understanding the role of subsidies (Ibid.: 21-28).

The state capitalism perspective emphasizes the role of the state in leading economic development in China (Aligica and Tarko 2012; Brenner 2010). While this article concurs with the basic tenets of the state capitalism perspective, it proposes a neo-institutional analysis as a way to bring attention to the norms and cognitive schemes governing the renewables sector. This position enables a more comprehensive discussion of the rationales and logics in play and, in turn, elucidates the mechanisms and dynamics that give weight to the concept of state capitalism itself.

Through case studies of biomass and solar PV companies, this article demonstrates that subsidies are perceived to be negotiable. Viewing this negotiability of subsidies as a norm rather than a stand-alone phenomenon adds to our understanding of the workings of the renewable energy sector. This article offers empirical insights into the role of subsidies, which are relevant to a growing number of companies - both Chinese and foreign - that aspire to succeed in China's renewable energy markets. This information can be important, for example, when making assessments regarding future subsidies, when lobbying for the issuance of subsidies, and when designing informed business strategies for the longer term.

When studying subsidization in an institutional perspective, attention must be paid to the wider context; institutionalization processes never take place in a vacuum. In this instance, the context will be examined through the concept of organizational fields, defined as a 'community of organizations that partakes of a common meaning system and whose participants interact more frequently and faithfully with one another than with actors outside of the field' (Scott 2008: 86). The organizational field of renewable energy in China comprises companies, various government agencies, China's Communist Party, business associations, and NGOs (Christensen 2013: 104-106). Moreover, renewable energy in China can be described as an emergent, and the structuration of the field is ongoing and open-ended (Maguire et al. 2004: 659; Fligstein 1997; Gray 1985: 912).

The article is structured in three main sections. First, recent studies on subsidies are discussed and shortcomings in the literature are identified. Secondly, two case studies and the related methodological issues are 
presented. Thirdly, the case findings are discussed from a neo-institutional perspective and, finally, some conclusions are offered.

\section{The Literature on Subsidies}

Within the neo-classical economic paradigm, subsidies are understood as state interventions in the functioning of the free market. States interfere in markets in many ways and on many grounds. All governments of market economies have, for instance, adopted and implemented competition laws: a set of rules that specify the national conditions for competition in legal terms. Due to the huge differences in the size between national economies, these vary a lot from state to state. On a more general level, states shape the foundations of any modern economy through the establishment of educational systems and rule of law (or rule by law, as it is practiced in China); they shape the frameworks for markets through labour market regulations, competition law, bankruptcy laws and property rights; and they intervene directly through innovation and industrial policymaking like subsidization (North 1981: 206). In the Western world, however, many of these direct interventions have been limited due to the dominance of the new classical economics and its belief in the ability of the free market to regulate itself in the most efficient way (Wade 1990:13). This is reflected, for instance, in the Western-dominated trade regime governed by the World Trade Organization (WTO), which prohibits trade in subsidized goods (regulated under the anti-dumping and anti-subsidy sections).

In the new classical economic literature, we find two main arguments that justify state interventions. Firstly, it is argued that industries in their infancy could benefit from both subsidies (to develop technologies, for example) and high tariff barriers, as a way to protect the industry from being exposed to competition from the world market before it has achieved better economies of scale (Chang 2002: 243). These measures would, however, be accepted only as short-term arrangements aimed at bringing the industry out of its infancy. Secondly, subsidies can be defended as a way of supporting industries with fewer negative externalities than the existing alternatives. This would very much apply to renewable energy, as subsidies make it a viable substitute for coal-based energy production, which has lots of negative externalities, such as pollution and climate change, on the surrounding society.

These two justifications of subsidies notwithstanding, the issue of interventions in (free) market operation seems to be contested in most, 
if not all, Western societies. On the one hand, public or political pressure in favour of interference (e.g. protectionist measures) can easily be mobilized in times of crisis. On the other hand, the argument that interference of any kind in free market operations is harmful (i.e. less efficient in the long run) is also an easily accessible political platform, though its popularity varies over time and across nation states. In China, the one-party rule does not leave room for any political lines of conflict with regard to state interventions in the shape of subsidization. Instead, the key issue is how subsidization in particular, and interventions in general, are perceived and executed by the ruling party. I will return to these aspects throughout the article.

Subsidies for renewable energy in China come in many forms. From the subtle 'favourable lending environment' orchestrated by the stateowned banks to the overt and rule-based reimbursements of installation costs and extra premiums paid by the state per $\mathrm{kWh}$ of renewable energy produced. The specific forms of subsidization for biomass and solar power will be discussed in the two case studies that follow.

The most recent study of subsidization of China's industry is Haley and Haley's analysis of subsidies for four capital-intensive industries: steel, glass, paper and auto-parts (Haley and Haley 2013). Their starting point is the apparent paradox that China has gained a competitive edge in developing capital-intensive industries, when the country's comparative advantage was cheap labour. Haley and Haley explain this apparent paradox in terms of subsidization, and are able to construct a model for measuring the actual scale of subsidies to particular industries. However, when closing in on the motives and reasoning behind the documented efforts by the Chinese state, the existing economic literature offers few insights. Economic (textbook) rationales in favour of subsidies are scarce, and the overwhelming consensus points to the distortion they cause and the fact that they lead to inefficient allocation of resources. Thus China's behaviour cannot be explained by an economic rationale. As Haley and Haley put it: 'when governmental decisions to grant subsidies have little to do with efficiency considerations, as in China, economic analysis based on welfare analysis offers few insights' (Haley and Haley 2013: 10). Instead they seek sociopolitical rationales for Chinese subsidies and arrive at a state capitalist perspective. In state capitalism, interventions in market operations are an embedded part of the model, and the state takes on a leading role in guiding economic development, through state owned enterprises as key players in selected sectors, for instance (Aligica and Tarko 2012; Brenner 2010; Screpanti 1999; Evans 1995). 
While state capitalism is a useful concept that emphasizes certain critical features of China's political-economic system, it remains a theoretical abstraction. In order to understand the actual rationales and sources of legitimacy on which real decisions are based on a societal level, more finegrained and operational theoretical tools are needed. Neo-institutional theory, with its strong focus on empirical studies, fulfils this requirement (Powell and DiMaggio 1991). Neo-institutional theory allows for analysis of the norms governing subsidization and the deeply institutionalized cultural-cognitive schemes and logics that make up the systems of meaning underpinning renewable energy in China (Scott 2014).

\section{Case Studies}

\section{Methodological Implications}

The two case studies presented here are informed by two relatively brief periods of fieldwork in Beijing and Shanghai in October 2008 and July 2009, respectively. The use of case studies has been recognized as a viable method when the research has an explanatory aim, as in this case (Yin 1994).

The first field trip specifically targeted one company, Dragon Power, which builds and operates biomass power plants. The second trip had a broader aim and targeted mainly solar (PV) power companies in the Shanghai area. The data derived from the two field trips consists of written material provided by the companies and a total of sixteen interviews, of which thirteen were with business people on both executive and management levels, two were with NGOs, and one with a government agency.

The first case is based on six interviews with most of the executive level employees of Dragon Power, as well as the founder of the company, one board member, and one government director from the National Development and Reform Commission (NDRC). The first pilot interview was conducted with the board member (who is Danish), who later helped to open the door to access the executive level in Dragon Power. Notably, it only took a few interviews before the same key company storylines began to be repeated. This was likely due to the relatively small group of executives working closely together on a daily basis. Saturation was therefore achieved on the basis of these few focused interviews with relevant informants who were well-positioned to discuss the decisions and events targeted by the case study. 
The second case study is based on ten interviews with managers from four different solar (PV) producers (Suntech Power Holding 2, Solarfun Power Holding 1, Shanghai Topsolar Green Energy Company 1, Eoplly New Energy Technology 2), representatives from two renewable energy associations (Chinese Renewable Energy Industries Association (CREIA), and Renewable Energy and Energy Efficiency Partnership (REEEP)), one interview with the vice president of Suzlon Energy (the Beijing branch office of an Indian wind turbine producer), and one interview with a manager at China Huaneng Corporation, one of 'the big five' energy companies in China. The aim of this line of interviews was to attain a broader understanding of renewable energy in the field and especially the solar (PV) industry's market situation and relations with government agencies.

As noted above, the two case studies are primarily based on these interviews. However, it is impossible to rely solely on interview data due to the relatively limited sample. Furthermore, all companies have an interest in presenting themselves in a favourable light and this could lead to a company-centric worldview and bias in how they describe their own role and impact. To compensate for the bias and limited number of informants a number of steps were taken. First, with regard to the Dragon Power case, an interview with the director of NDRC (Dragon Power's main government counterpart) was organized. As interviews with NDRC staff are notoriously difficult to obtain, this provided a rare opportunity to cross-check Dragon Power's explanations of their dealings with NDRC. Secondly, written material - for instance the 'Louyang Declaration', which figures prominently in the second case study - was used to check chronology and accuracy of wording, and to confirm the information obtained through the interviews. Third, it is worth noting that the issues dealt with in both case studies are easy to verify, and were not considered controversial by the informants.

\section{Case 1: Biomass}

Before 2006 there were no subsidies for power produced through biomass combustion. In fact, as late as 2003, biomass was not even mentioned in official Chinese documents on renewable energy. ${ }^{1}$ Today, biomass power is economically feasible in China due to a state subsidy. The subsidy is therefore the point of rotation for this business and a key condition for biomass companies' ability to compete with coal fired power plants. The specific subsidy was introduced in 2006 and is called a feed-in tariff. It is basically a premium price that the state pays per 
$\mathrm{kWh}$ produced on top of the standard price of electricity (which is, at least in the longer run, based on the price of coal).

Also in 2006, Dragon Power established the Shanxian plant, the first biomass (straw-fired) power plant in China. This first plant was, however, the product of a three year process in which the founder of Dragon Power, Kai Johan Jiang, and a few colleagues had worked intensively to acquire a special license from the NDRC that would allow them to build power plants with a capacity below the national threshold of 50 MW. By 2011, Dragon Power had built and was operating 19 biomass power plants, had an additional 13 in the pipeline and employed 8000 people. They had become the biggest biomass power company not only in China, but in the world. In the Chinese market they were without any significant competitors. And as an illustration of Dragon Power's entrepreneurial nature it is worth noting that the establishment of the Shanxian plant was initiated before any subsidy was in place.

In the 'Renewable Energy Law' document, biomass power is listed alongside hydro, wind and solar as one of four sources of renewable energy recognized in China (Renewable Energy Law 2007). Through this law the Chinese state commits itself to promote biomass and, as promised, just after it was promulgated a feed-in tariff on RMB 0.25 per kWh was granted.

When explaining Dragon Power's short history, its president, Simon Parker, mentioned Dragon Power's influence on the crucial renewable energy law and the subsidy:

'There were people within our organization who were actually involved in drafting, commenting on the Renewable Energy Law... the creation of the law, which gives... it is for any company who would qualify for it, but we were... at the inception of the creation of an industry [biomass] in China [when] we made Dragon Power...' ${ }^{2}$

In this quotation Simon Parker hints at the fact that the main beneficiary of this subsidy was and remains Dragon Power.

In a subsequent interview with the director of NDRC it was confirmed that Dragon Power did indeed introduce biomass to China (and the NDRC). ${ }^{3}$ And, as noted, this is also evidenced by the fact that biomass is not even mentioned in official documents published by the NDRC as late as 2003. NDRC is the main government agency for exercising government interests and implementing projects in the energy sector (as well as all other politically prioritized sectors) and it has remained Dragon Power's main government counterpart throughout the company's short history. 
In the follow up to the Renewable Energy Law called Medium and Long Term Renewable Energy Development Plan published in August 2007, it was stipulated that China should reach an installed capacity of $5.5 \mathrm{GW}$ in 2010 and $30 \mathrm{GW}$ by 2020 (NDRC 2007a). ${ }^{4}$ To reach at least the short term milestone the Chinese state (and NDRC as the responsible agency) was therefore totally depending on Dragon Power's success. ${ }^{5}$ Moreover, without a continuous build up of Dragon Power's capacity it will be impossible to reach the longer-term target.

The subsidy of RMB 0.25 per $\mathrm{kWh}$ was, according to the president of Dragon Power, just a first attempt to find a reasonable price level. A few years later, when it became apparent that Dragon Power would struggle to make a profitable business, another RMB 0.10 of premium was added to the existing subsidy. Again, Dragon Power was the sole beneficiary. Asked directly about Dragon Power's influence on this extra premium, Simon Parker stated:

'I don't have anything that can tangibly show that to be the case. What you can see is since the creation of the industry and the Renewable Energy Law was devised there have been additional incentives provided for biomass at a couple of different stages to ensure that the revenue receipts enabled the industry to be viable. And when you talk about the industry at the moment, NBE [a Dragon Power subsidiary] is $80-90 \%$ of the biomass industry. So other than connecting the dots...'

Specifically on this extra premium, the director of NDRC stated:

'Prices have gone up, for instance on steel used in the construction. It was difficult to do business so we talked to Dragon Power'. ${ }^{6}$

This commentary shows exactly how involved Dragon Power was in establishing and (upwardly) adjusting this subsidy in very close relationship with NDRC.It is also important to notice that this was no trivial matter, as a subsidy was a 'make or break' factor for this particular company in terms of its ability to compete with other renewable energy solutions and non-renewable coal based energy production. In China, close connections to government agencies are openly affirmed as a company asset. This was reflected in all the interviews I conducted for both case studies, although the actual extent of business influence on government agencies is another matter. In this particular case, it is significant and reveals the extent of NDRC's dependence on Dragon Power to reach the short term milestone. This dependence also meant that the normally quite asymmetrical relationship between the powerful NDRC and a single company was levelled out, and could more accurately be described as a negotiation between equal partners. 


\section{Case 2: Solar Power}

The second case study focuses on the part of the renewable energy industry that deals with solar power or, more narrowly defined, with photo voltaic (PV) energy. In 2008 the Chinese solar industry was exporting between 90 to 95 per cent of its production to other markets, mainly Germany and Spain (United Steel 2010: 195). The Chinese market for solar power was therefore negligible and had not been an important driver for the massive industrial expansion that had already taken place. ${ }^{7}$ So for these solar power companies, which were mostly privately owned and located in China because of the low (and, according to Haley and Haley, highly subsidized) production costs, a boost to their home market would be enormously helpful, not least in the midst of a global economic downturn (Haley and Haley 2013).

A solar subsidy for the Chinese market would make it possible for solar power to compete with the standard price of electricity, which is set by the government and is linked to the price of coal. ${ }^{8}$ This means that a Chinese subsidy, especially a feed-in tariff, would have an immediate effect on the size of the market for solar power in China.

In 2001, a Chinese solar engineer named Mr Shi Zhengrong founded Suntech and started to manufacture solar cells. By 2007, the company had grown to be the world's third largest competitor in solar power and was regarded as an industry leader. This also meant that Mr Shi was an influential person in 'green' business. Initiated by $\mathrm{Mr}$ Shi, a number of the Chinese solar giants including Suntech, LDK, Trina, Solarfun and Canadian Solar (all publicly listed companies) got together for a PV industry meeting on 18 December 2008 where they agreed on an industry pricing roadmap. This pricing roadmap was finalized by Suntech and Trina and subsequently handed over to the Chinese Ministry of Science and Technology (MOST). ${ }^{9}$ The roadmap stipulated that the industry should make a concerted effort to lower the on-grid solar power price to RMB 1 per kilowatt hour (kWh) by 2012. The phrase 'RMB 1 per kWh' was coined and promoted by Mr Shi and Suntech. For solar power, 'RMB 1 per $\mathrm{kWh}$ ' was said to be the threshold for large-scale commercialization of this particular energy source. At this level, solar energy would be affordable even without subsidies from the state.

The following year, on 28 April at the 2009 China Solar PV Industry Annual Conference held in the city of Luoyang, Mr Shi managed to orchestrate what became known as the 'Louyang Declaration', which was jointly issued by 13 leading Chinese solar photovoltaic companies (see below, Louyang Declaration 2009). With this declaration the companies 
committed themselves to lowering prices throughout each stage of the production of a solar cell panel and thereby reach the 'RMB 1 per $k W h$ ' target. At the time of the conference, solar power was priced at about RMB 4 per $\mathrm{kWh}$, which was calculated on the basis of production costs and the amount of energy a solar module can produce over 20 years, the standard warranty period in the business.

The list above shows that all the biggest companies in the Chinese market for solar energy (PV) participated in this meeting. It also shows that all types of producers from the whole value chain participated and that there were many overlaps, meaning that most of the companies were benched alongside their biggest competitors as well as their closest partners. Government officials from the NDRC were also present at the meeting. The particular constellation of actors therefore illustrates that the 'Louyang Declaration' and the conference were very much about the interests of the sector as a whole.

When asked about the reasons for promoting the ' 1 RMB per $k W h$ ' phrase, a director from Suntech gave the following illustrative and rather blunt response:

'[A] year or two ago Dr Shi started talking about ' 1 RMB per $k W h$ ' as the target for solar and at the time people said that was crazy and we won't be able to achieve it. But it basically set the benchmark for policy-makers in the solar industry to move towards. And now probably everybody believes we can do it. And policy-makers also see that as the goal and so the idea is to get policy-makers to introduce subsidies that help take us to that point'.11

In this light, the 'Louyang Declaration' becomes a clear and public communication directly targeting the NDRC and MOST. The conference, and the discussions and preparations that preceded it, become an integrative effort where industry and government clarify their respective positions. A common platform has been established through the framing of both the 'RMB 1 per $\mathrm{kWh}$ ' and the 'Louyang Declaration' as ways to further a sustainable use of energy.

But why has the Chinese government not introduced a subsidy as other governments have? Germany and Spain, for instance, have a feedin tariff, which means that all owners of a solar module which is connected to the grid are paid for the electricity they produce. When asked about this absent Chinese subsidy, the director of Suntech replied:

'They [the government] thought it was too expensive. You can only set a feed-in tariff if it is feasible. They just didn't introduce it until a point where it was economically viable. ${ }^{12}$ 
TABLE 1. Signatories of the 'Louyang Declaration'10

\begin{tabular}{|c|c|c|}
\hline $\begin{array}{l}\text { Suntech Power Co., } \\
\text { Ltd }\end{array}$ & $\begin{array}{l}\text { Cell, module and } \\
\text { system production }\end{array}$ & $\begin{array}{l}\text { Headquartered in Wuxi, China. } \\
\text { Publicly listed on New York Stock } \\
\text { Exchange }\end{array}$ \\
\hline $\begin{array}{l}\text { Yingli Green Energy } \\
\text { Holding Co., Ltd }\end{array}$ & $\begin{array}{l}\text { Ingots, wafers, cell and } \\
\text { module production }\end{array}$ & $\begin{array}{l}\text { Headquartered in Baoding, China. } \\
\text { Publicly listed on New York Stock } \\
\text { Exchange }\end{array}$ \\
\hline $\begin{array}{l}\text { JA Solar Holdings Co., } \\
\text { Ltd }\end{array}$ & Cell production & $\begin{array}{l}\text { Headquartered in Shanghai, China } \\
\text { Publicly listed on NASDAQ }\end{array}$ \\
\hline LDK Solar Co., Ltd & $\begin{array}{l}\text { Polysilicon, wafers } \\
\text { production }\end{array}$ & $\begin{array}{l}\text { Headquartered in Xinyu, China. } \\
\text { Publicly listed on New York Stock } \\
\text { Exchange }\end{array}$ \\
\hline $\begin{array}{l}\text { Beijing Jingyuntong } \\
\text { Technology Co., Ltd }\end{array}$ & $\begin{array}{l}\text { Polysilicon, wafers } \\
\text { production }\end{array}$ & Headquartered in Beijing, China. \\
\hline $\begin{array}{l}\text { China Silicon } \\
\text { Corporation, Ltd }\end{array}$ & Polysilicon production & Headquartered in Louyang, China \\
\hline $\begin{array}{l}\text { Sichuan Xinguang } \\
\text { Silicon Technology Co., } \\
\text { Ltd }\end{array}$ & Polysilicon production & Headquartered in Leshan, China \\
\hline \begin{tabular}{l|} 
Emei Semiconductor \\
Materials Factory
\end{tabular} & Polysilicon production & Headquartered in Chengdu, China \\
\hline Jiangsu Shunda Group & $\begin{array}{l}\text { Ingots, wafers, cells } \\
\text { and module } \\
\text { production }\end{array}$ & $\begin{array}{l}\text { Headquartered in Yangzhou, } \\
\text { China }\end{array}$ \\
\hline $\begin{array}{l}\text { No.45 Research } \\
\text { Institute of China } \\
\text { Electronics Technology } \\
\text { Group Corp }\end{array}$ & $\begin{array}{l}\text { Semiconductor } \\
\text { Equipment }\end{array}$ & Headquartered in Beijing, China. \\
\hline $\begin{array}{l}\text { Daqo New Energy } \\
\text { Corp }\end{array}$ & $\begin{array}{l}\text { Polysilicon, ingots, } \\
\text { wafers, cell and } \\
\text { module production }\end{array}$ & $\begin{array}{l}\text { Headquartered in Chongqing, } \\
\text { China. } \\
\text { Publicly listed on New York Stock } \\
\text { Exchange }\end{array}$ \\
\hline $\begin{array}{l}\text { GCL-Poly Energy } \\
\text { Holdings Limited }\end{array}$ & $\begin{array}{l}\text { Polysilicon and wafer } \\
\text { production }\end{array}$ & $\begin{array}{l}\text { Headquartered in Hong Kong, } \\
\text { China. } \\
\text { Publicly listed on Hong Kong } \\
\text { Stock Exchange }\end{array}$ \\
\hline $\begin{array}{l}\text { China Electronics Tech- } \\
\text { nology Group Corpo- } \\
\text { ration 48th Research } \\
\text { Institute }\end{array}$ & $\begin{array}{l}\text { Ingots, wafers, cell and } \\
\text { module production }\end{array}$ & $\begin{array}{l}\text { State Owned Enterprise, } \\
\text { headquartered in Changsha, China }\end{array}$ \\
\hline
\end{tabular}

Thus, the 'Louyang Declaration' is the industry's attempt to show the government that they are approaching the point where a subsidy would be 'economically viable'.

Have the 'RMB 1 per kWh' phrase and the 'Louyang Declaration' had any effect? This is difficult to assess in the short run, but notably - on 
23 March 2009, after the 'RMB 1 per $\mathrm{kWh}$ ' roadmap was presented but before the 'Louyang Declaration' was formulated - the Chinese Ministry of Finance and the Ministry of Housing and Urban-Rural Development issued the 'Solar Roof Plan', which subsidizes 'built-in PV' with $20 \mathrm{RMB} / \mathrm{W}$ and $15 \mathrm{RMB} / \mathrm{W}$ for roof top applications (both for systems with a capacity above $50 \mathrm{~kW}) .{ }^{13}$ This kind of subsidy thereby covers some of the investment costs.

In addition, three months after the 'Louyang Declaration', on 21 July 2009, the Ministry of Finance, Ministry of Science and Technology and National Energy Administration (which is under the NDRC) issued a joint statement that announced a 'Golden Sun' programme. This programme targeted demonstration projects and subsidizes $50 \%$ of the investment costs for on-grid projects and 70 percent of the costs for independent projects (United Steel 2010).

Moreover, in May 2010 a formal alliance, named China Photovoltaic Industry Alliance (CPIA), was created. CPIA comprises some of the same companies (though not exclusively) that participated in the Louyang meeting, along with government bodies like NDRC and Ministry of Industry and Information Technology (MIIT). Reportedly, this alliance was proposed at the Louyang meeting by Wang Bohua, director of MIIT. ${ }^{14}$ CPIA was established with the aim of aligning technologies, developing and implementing industry standards, as well as enabling a more accurate collection of industry data in order to help support government policies to guide the development of the industry. ${ }^{15}$ The alliance therefore signals a commitment to a cooperative relationship in the future. The crucial point is that these meetings took place at all, that thinking, facilitating and enacting these events made sense to the participants: both companies and government. These events therefore bear witness to a shared expectation about the negotiability of subsidies.

\section{Case Findings: Negotiability as the Norm}

What do the two case studies tell us about subsidization in China's renewable energy industry? The first case, Dragon Power, is extreme in the sense that the negotiability of the subsidy level is so obvious. A feed-in tariff is decided upon and even increased, and all along one company is the sole beneficiary. With the case of solar power companies is less clear-cut, but there is nonetheless an expectation of negotiability. This expectation has to some extent been met, given 
the subsequent launch of subsidy programmes and the establishment of a formal alliance between companies and government agencies. Moreover, as evidenced by the candid descriptions of these events by both companies and Party-state, the negotiation of subsidies is obviously deemed appropriate behaviour and negotiability seems to be taken for granted.

From the outset, it is clearly in the interest of companies to engage in such negotiations, because they are essentially negotiating to improve their ability to perform economically. ${ }^{16}$ The interesting aspect, however, is that this expectation of negotiability is shared by the Party-state. This shared expectation, and sense of appropriateness and taken-for-grantedness, are strong indicators of an institutionalization of negotiability (Scott 2014: 60). It therefore makes sense to view this negotiability as a norm underpinning and stipulating the appropriate way to deal with subsidies.

\section{Enabling Negotiability}

Where does this norm of negotiability of subsidies come from? How is it made possible? On what grounds are these negotiations legitimized? In the following these questions are discussed based on the more fundamental and deeply institutionalized meaning systems governing the area: what Scott describes as the 'cultural-cognitive dimensions' (Scott 2014: 67).

From the outset, and as illustrated by the two case studies, subsidies are very much about relations between two of the most fundamental logics in contemporary history: state and market (Friedland and Alford 1991). In the Chinese context this relationship is complicated by the country's economic past and relatively recent engagement with market reforms. The gradual top-down embrace of market mechanisms, the ideological overlay and need for flexible handling of different forms of ownership (and consequently property rights), the existence and persistence of dominant state-owned enterprises with huge market shares, and not least the lack of a moral or individualistic platform from which the free market in China can be defended, have left the borders between state and markets far more malleable than in Western economies (Christensen 2010; Nolan 2004: 84, 175). Consequently, the Chinese way of handling relations between state and market enables a very favourable environment for developing subsidy schemes in order to support businesses and maintain high growth rates. 
However, the drive for renewable energy is also important. The background for this massive effort, which has propelled China to become the world's biggest investor in renewable energy, is a wide-ranging turn towards a more sustainable development track (Christensen 2013: 81-100). A more holistic perspective that encompasses economy, population, society and environment has been called for from the top of the Communist Party of China in order to lessen the impact on natural resources and living conditions. These ideals have been brought together under the concept of 'sustainable development', which is now used to direct and legitimize the large-scale subsidization of renewable energy (ibid), including the Renewable Energy Law.

While the more structural subsidies to capital intensive industries documented by Haley and Haley (2013) could be rooted in the malleable state-market relation described above, the subsidies for renewable energy, and other specific subsidies for specific industries, only make sense and achieve legitimacy in the context of this turn towards sustainable development. The industry simply has to be targeted for special attention, which is exactly what has happened with renewable energy under the sustainable development drive. On the one hand, this means that sustainable development as a new policy direction makes it possible for companies to 'invite the state in' (with its subsidy schemes), as exemplified by the 'Louyang Declaration' (2009). On the other hand, it also means that the market logic is degraded further. In the case of Dragon Power this was taken to an extreme in the sense that the company was actually handed a monopoly on biomass in China. ${ }^{17}$ Thus, the particular combination of institutional logics (state and market), as well as the comprehensive turn towards more sustainable development, is key to understanding the negotiability of subsidies for renewable energy in China.

\section{Negotiability and Bargaining Power}

A common theoretical misunderstanding of the notion of a norm is to view it as a sphere of social interaction devoid of power relations. Negotiability is a legitimate way of dealing with subsidies for renewable energy in China, and it does not say anything about the actual result of the negotiation or the bargaining power that different agents, companies and government, entering into negotiations may hold. Negotiability is open-ended and there is wide scope for agency in the form of strategizing and leverage of bargaining power (Scott 2014: 94). In the case 
studies presented above, bargaining power would be defined in terms of companies' ability to create growth, jobs and government revenue though taxes, as these are important government targets. The ability of companies to utilize their network (guanxi) through relevant administrative units would also determine the bargaining power of companies. Moreover, the political weight attributed to sustainable development could also influence the distribution of bargaining power. For instance, due to the importance that the Chinese government attaches to fulfilling its renewable energy targets, Dragon Power could be expected to have the upper hand in negotiations, because they were the only company with the capacity to meet the biomass target.

Secondly, there is an obvious power play around the norm in the sense that the norm only applies to renewable energy companies, rather than energy companies in general. Only businesses defined as renewable are considered to be legitimate negotiation partners by the government. It was therefore a crucial turning point for Dragon Power when biomass was listed as a form of renewable energy in the Renewable Energy Law.

Thirdly, the creation of the norm (the institutionalization process) is also about a play of power among the involved agents (Scott 2014: 115). The enabling conditions discussed above have been used by companies to push for negotiations of subsidies and for keeping the door open for continued negotiations. However, once the norm is in place the power play that preceded it fades from memory and new renewable energy companies will not have to push to the same extent for negotiations; the door is already open.

\section{Conclusion}

The neo-institutional perspective makes it possible to see the institutional features of subsidization and thus, the key subject of this study: the norm of negotiability of subsidies. On this basis, it can be assumed that that the negotiability of subsidies is unlikely to cease in the shortterm, because it has the properties of an institutionalized norm and institutions are in general sticky and able to resist change.

Moreover, on an empirical level the two case studies illustrate that the nature of the relationship between companies and the Party-state is dynamic and cooperative. While this is a well-known feature of relations between companies and Party-state in China, it has not been documented with respect to crucial market enabling subsidies, such as 
the case of biomass. It is therefore reasonable to see this feature as one of the key micro-mechanisms that has enabled China's leading position within renewable energy.

This dynamic relationship and the scope of negotiability also has consequences for business strategies in the field. Where Haley and Haley's work has shown the importance of understanding the role of subsidies when assessing markets, production locations and competitiveness of rivals (Haley and Haley 2013: 176-178), this study emphasizes how bigger companies should not take specific subsidies at face value when they are actually negotiable. And for new or incoming companies with new technologies and renewable solutions, both cases have clearly illustrated that completely new subsidies can be launched at short notice. The speed and flexibility with which markets can develop in China will continue to be a key attraction to companies worldwide. It does, however, require that companies are able to tap into policy regimes, like sustainable development, as well grasping the more malleable state-market relations that characterize the Chinese economy. This will remain a particular challenge for new foreign companies entering China's renewable energy sector.

The negotiability of subsidies norm also adds to our understanding of the workings of state capitalism in China. It reveals how companies are playing a key role in shaping the sector, which suggests a more open-ended and less state-orchestrated development than sometimes assumed.

Nis Høyrup Christensen, PhD, is Assistant Professor at the Asia Research Centre, Department of International Economics and Management, Copenhagen Business School. His research focuses on state-market relations in China. Email:nhc.int@cbs.dk

\section{NOTES}

1 Biomass is not mentioned in the official follow up on China's Agenda 21, which is called 'Program of Action for Sustainable Development in China in the Early 21st Century' and published by the NDRC in 2003 (NDRC 2003).

2 Interview with Simon Parker, President, Dragon Power, Beijing, October 2008.

3 Interview with Liang Zhipeng, Ph.D., Director, Renewable Energy \& Rural Power Division, Energy Bureau, National Development and Reform Commission, Beijing, October 2008.

4 There was 2GW installed capacity by the end of (NDRC 2007).

5 This was also the explicit understanding held by Dragon Power's president.

6 Interview with Liang Zhipeng, Ph.D., Director, Renewable Energy \& Rural Power 
Division, Energy Bureau, National Development and Reform Commission, Beijing, October 2008.

7 The first subsidies specifically aimed at boosting the Chinese market were launched in 2009. See 'China's Policies Affecting Trade and Investments in Green Technology' (United Steel 2010)

8 Whereas the price on coal fluctuates according to supply and demand, the price of electricity is kept stable by the government.

9 See 'Green Hopes: Energy Law \& Plan, Big 5 Subsidized, Installed Wind Doubles' at http:/ / greenleapforward.com/2009/02/13/green-hops-energy-law-plan-big-5subsidized-installed-wind-doubles/. Accessed 23 April 2015.

10 See 'The Louyang Declaration' (Louyang Declaration 2009).

11 Interview with Rory Macpherson, Investor Relations Director at Suntech Power Holdings Co., Ltd., Shanghai, October 2009.

12 Interview with Rory Macpherson, Investor Relations Director at Suntech Power Holdings Co., Ltd., Shanghai, October 2009.

13 These subsidies were also a part of the Chinese government's RMB 4 trillion economic stimuli package to boost up the economy after the (Western) financial crisis and global economic downturn.

14 See: 'PV Industry set up behind the Union' at http://www.publiku.com/blog. php? user $=$ lqbatteryshop\&note $=186025$. Accessed 8 November 2010.

15 See: 'PV Industry set up behind the Union' at http://www.publiku.com/blog. php? user=lqbatteryshop\&note $=186025$. Accessed 8 November 2010, and 'China officially proclaimed photovoltaic industry federation' at http://www.shundasolar. com/eng/aboutus_news_show.asp?id=251. Accessed 8 November 2010.

16 This follows from the basic fact that to companies in the Chinese market for renewable energy a subsidy is make or break: otherwise they would not be able to compete with the coal price of electricity.

17 Though the monopoly is to some extent countered by the Chinese state's role as monopsonist, the sole buyer of biomass (Endres 1997: 143).

\section{REFERENCES}

Aligica, P. and V. Tarko 2012. 'State Capitalism and the Rent-Seeking Conjecture.' Constitutional Political Economy 23(4): 357-379.

Brenner, I. 2010. The End of the Free Market: Who Wins the War Between States and Corporations. London: Portfolio.

Chang, Ha-Joon 2002. Kicking Away the Ladder: Development Strategy in Historical Perspective. London: Anthem Press.

Christensen, Nis H. 2013. Shaping Markets: a Neoinstitutional Analysis of the Emerging Organizational Field of Renewable Energy in China. Copenhagen: Copenhagen Business School.

Christensen, Nis H. 2010. 'Kinas frie marked - og hvorfor grænsen mellem stat og marked så let overskrides' in Offentligt eller privat? Historiske og aktuelle udfordringer i politik og økonomi. (eds) L.B. Kaspersen, J. Lund and O.H. Pedersen. Copenhagen: Jurist- og Økonomforbundets Forlag: 37-51.

Endres, A.M. 1997. Neoclassical Microeconomic Theory: The Founding Austrian Version. London: Routledge.

Evans, P. 1995. Embedded autonomy: States and industrial transformation. Princeton: Princeton University Press.

Fligstein, N. 1997. 'Social skill and institutional theory.' American Behavioral Scientist 
40(4): 397-405.

Friedland, R. and R. R. Alford 1991. 'Bringing Society Back In: Symbols, Practices, and Institutional Contradictions' in The New Institutionalism in Organizational Analysis (eds) W.W. Powell and P.J. DiMaggio. Chicago: University of Chicago Press: 232263.

Gray, B. 1985. 'Conditions facilitating interorganizational collaboration.' Human Relations 38(10): 911-936.

Haley, U.C.V. and G.T. Haley 2013. Subsidies to Chinese industry: state capitalism, business strategy and trade policy. New York: Oxford University Press.

Louyang Declaration 2009. 'The Louyang Declaration' at http://basis.cena.com.cn/ ICyejie/2009-04-28/124089309830243.shtml. Accessed 11 November 2010.

Maguire, S., C. Hardy and T.B. Lawrence 2004. 'Institutional Entrepreneurship in Emerging Fields: HIV/Aids Treatment Advocacy in Canada.' Academy of Management Journal 47(5): 657-679.

Nolan, P. 2004. China at the Crossroads. Cambridge: Polity Press.

North, D.C. 1981. Structure and Change in Economic History. New York: W. W. Norton \& Company, Inc. NDRC 2007. 'Medium and Long Term Renewable Energy Development Plan.' Published by National Development and Reform Commission at http://www.chinagate.cn/reports/2007-09/13/content_8872839.htm. Accessed 23 April 2015.

NDRC 2003. 'Program of Action for Sustainable Development in the Early 21st Century.' Published by National Development and Reform Commission at http://en.ndrc. gov.cn/newsrelease/t20070205_115702.htm. Accessed 5 February 2007.

Powell, W.W. and P.J. DiMaggio (eds) 1991. The New Institutionalism in Organizational Analysis. Chicago: University of Chicago Press.

Renewable Energy Law 2007. 'Renewable Energy Law of the People's Republic of China.' Published by Ministry of Commerce People's Republic of China at http:/ / english. mofcom.gov.cn/article/policyrelease/questions/201312/20131200432160.shtml. Accessed 23 April 2015.

Scott, W.R. 2014. Institutions and organization: ideas, interest, and identities. 4th edition. California: SAGE Publications, Inc.

Scott, W.R. 2008. Institutions and organizations: Ideas and interests. 3rd edition. California: Sage Publications, Inc.

Screpanti, E. 1999. 'Capitalist Forms and the Essence of Capitalism.' Review of International Political Economy 6(1): 1-26.

United Steel 2010. 'China's Policies Affecting Trade and Investments in Green Technology.' Published by The United Steel, Paper and Forestry, Rubber, Manufacturing, Energy, Allied Industrial and Service Workers International Union at https:/ / ustr.gov/ sites/default/files/09-09-2010\%20Petition.pdf. Accessed 9 Sptember 2010.

Wade, R. 1990. Governing the Market: Economic Theory and the Role of Government in East Asian Industrialization. New Jersey: Princeton University Press.

Yin, R.K. 1994. Case Study Research: Design and Methods. 2nd edition. California: Sage Publications. 